\title{
Penilaian Efisiensi Dengan Data Envelopment Analysis Pada Bank Umum Syariah (BUSN Devisa dan Non Devisa)
}

\author{
Oleh: Desmy Riani
}

\begin{abstract}
ABSTRAK
Tujuan penelitian ini dilakukan untuk menganalisis efisiensi bank umum syariah devisa dan non devisa di Indonesia dengan metode Data Envelopment Analysis periode 2013-2017. Teknik pengambilan sampel dalam penelitian ini dengan menggunakan purposive sampling sehingga menghasilkan sampel 10 bank umum syariah yang terdiri dari 4 bank umum syariah devisa dan 6 bank umum syariah non devisa. Data yang diperlukan dalam penelitian ini diperoleh dari website bi.go.id, metode analisis yang digunakan adalah DEA untuk menganalisa efisiensi teknik pada bank syariah dan uji deskriptif data menggunakan program SPSS 2.1. Hasil penelitian menunjukkan terdapat tiga bank umum syariah yang konsisten efisien 100 persen dari tahun 2013-2017 yaitu Bank Muamalat dan Bank Syariah Mandiri pada pendekatan intermediasi yang berasumsikan VRS dan pada pendekatan produksi yang berasumsikan CRS dan VRS. Serta Bank Bank Victoria Syariah pada pendekatan intermediasi dan pendekatan produksi yang berasumsikan VRS. Bank Muamalat dan Bank Syariah Mandiri merupakan bank umum syariah devisa. Bank Victoria Syariah merupakan bank umum syariah non devisa. Sedangakan efisiensi pada bank umum syariah lainnya selama periode 2013-2017 mengalami fluktuasi dan efisiensi bank yang berasumsikan VRS mendapatkan nilai yg lebih tinggi atau lebih efisien dibandingkan yang berasumsikan CRS.
\end{abstract}

Kata Kunci: Efisiensi, Data Envelopment Analysis, Bank Umum Syariah.

\section{PENDAHULUAN}

Perbankan merupakan tonggak

utama dalam pengukuran pertumbuhan

ekonomi negara karena eksistensi suatu

bangsa dimata dunia internasional salah satunya bisa dilihat dari keberhasilannya

dalam mengelola pembangunan. Menurut

Ahmad Syakir Kurnia (2004), lembaga

keuangan khususnya perbankan di
Indonesia telah menjadi tulang punggung perekonomian negara di mana sebagai salah satu pelaku utama. Di Indonesia, perbankan mempunyai pangsa pasar sebesar 80 persen dari keseluruhan sistem keuangan yang ada (Zainal Abidin, 2007).

Semakin pesatnya perkembangan industri perbankan syariah di Indonesia semakin menuntut adanya pengukuran mengenai tingkat efisiensi bank syariah. 
Efisiensi merupakan hal yang sangat penting untuk mendapatkan perhatian agar perbankan syariah dapat berdaya saing, berkembang dan mampu berperan secara lebih optimal bagi pembangunan nasional. Menurut pendapat pendapat Mansyur (2012) menyatakan bahwa, salah satu aspek penting dalam pengukuran kinerja dan kompetisi di dunia perbankan adalah efisiensi, dimana efisiensi dapat ditingkatkan melalui penurunan biaya (reducing cost) dalam proses produksi ataupun dengan meningkatkan pendapatan.

Suatu perusahaan dikatakan memiliki tingkat efisiensi yang lebih tinggi jika dengan jumlah input tertentu dapat menghasilkan jumlah output lebih banyak atau pada jumlah output tertentu bias menggunakan input lebih sedikit (Abidin dan Endri, 2009). Efisiensi juga bisa diterjemahkan sebagaimana kemampuan untuk menyelesaikan suatu perkerjaan dengan benar atau didalam konsep matematika merupakan perhitungan rasio antara keluaran (output) dan masukan (input) (Handoko,1984). Dengan kata lain, efisiensi dapat diartikan sebagai cara untuk menghasilkan output yang ada dengan menggunakan input yang minimal (Hadad, dkk., 2003).

Indikator efisiensi dapat dilihat dengan memperhatikan besarnya rasio beban operasional terhadap pendapatan operasional (BOPO) dan dapat dilihat dengan memperhatikan rasio rentabilitas bank dalam memperoleh keuntungan atas sumber-sumber dana yang dimiliki atau biasa disebut dengan Return On Asset (ROA). Efisiensi perbankan selain diukur dengan melihat perbandingan indikator kinerja perbankan dan rasio keuangan, ada juga beberapa metode lain, yaitu pendekatan parametrik dan non parametrik. Pendekatan parametrik meliputi Stochastic Frontier Approach (SFA), Distribution Free Approach (DFA) dan Thick Frontier Approach (TFA), sedangkan non parametrik dengan pendekatan Data Envelopment Analysis (DEA). Menurut Subekti (2004), analisis 
kinerja bank berdasarkan rasio keuangan hanya menghasilkan prediksi klasifikasi bank saja, apakah kemudian suatu bank akan mengarah pada kebangkrutan atau keberhasilan, tanpa diketahui secara pasti faktor-faktor apa saja yang menyebabkan kemungkinan terjadinya kebangkrutan. Dengan analisis efisiensi perbankan berdasarkan model DEA, maka akan diperoleh suatu gambaran yang lebih jelas tentang faktor-faktor yang menyebabkan suatu bank menjadi tidak efisien.

Model DEA telah banyak diaplikasikan untuk mengukur efisiensi suatu bank. Golany dan Storbeck (1999) menggunakannya untuk mengevaluasi efisiensi relatif operasional cabang sebuah bank di Amerika dengan 14 kantor cabangnya. Zenios et al. (1999) juga menggunakan DEA untuk menilai efisiensi relatif cabang-cabang Bank of Cyprus dan menggunakan DEA sebagai dasar benchmarking antar-cabang. Sedangkan Barr et al. (2002) mengaplikasikan DEA guna mengevaluasi produktivitas, efisiensi dan kinerja Bank Komersil di Amerika Serikat (Wilson, 2006:141).

Pengukuran efisiensi dengan metode DEA, dapat memberikan nilai-nilai untuk tiap variabel input dan output agar bank dapat mencapai efisiensi yang ditampilkan dalam potential improvement. Sehingga dapat membantu perbankan untuk mengetahui kinerja bank tertutama pada efisiensi keuangan bank dan dapat dijadikan sebagai salah satu pedoman bagi manajer untuk mengambil keputusan di masa mendatang.

Penelitian ini bertujuan untuk menganalisis tingkat efisiensi Bank Umum Syariah selama periode 2013-2018 menggunakan metode Data Envelopment Analysis (DEA) dengan Intermediation approach, dan menganalisis tingkat efisiensi Bank Umum Syariah Devisa dan Non Devisa selama periode 2013-2017 menggunakan metode Data Envelopment Analysis (DEA) dengan Production approach. 
KERANGKA PEMIKIRAN TEORITIS

DAN PERUMUSAN HIPOTESIS

Menurut Jama'an (2008) Signaling

Theory mengemukakan tentang bagaimana

seharusnya sebuah perusahaan

memberikan sinyal kepada pengguna

laporan keuangan. Sinyal ini berupa

informasi mengenai apa yang sudah

dilakukan oleh manajemen untuk

merealisasikan keinginan pemilik. Sinyal

dapat berupa promosi atau informasi lain

yang menyatakan bahwa perusahaan

tersebut lebih baik daripada perusahaan

lain. Pada signalling theory, adapun

motivasi manajemen menyajikan informasi

keuangan diharapkan dapat memberikan

signal kemakmuran kepada pemilik

ataupun pemegang saham. Publikasi

laporan keuangan tahunan yang disajikan

oleh perusahaan akan dapat memberikan

signal pertumbuhan deviden maupun

perkembangan harga saham perusahaan

(Kusuma, 2006).

Efisiensi pada perbankan

merupakan informasi yang memberikan sinyal dalam kinerja suatu perbankan.

Apabila nilai efisiensi teknik pada

perbankan mencapai 100 persen maka

informasi tersebut dapat dikategorikan

sebagai sinyal baik karena

mengindikasikan kinerja perbankan yang

baik. Sebaliknya apabila nilai efisiensi

teknik pada perbankan semakin kecil dari

angka 100 persen maka informasi tersebut

dapat dikategorikan sebagai sinyal yang

jelek karena mengindikasikan kinerja

perbankan yang kurang efisien.

Bank adalah badan usaha yang menghimpun dana dari masyarakat dalam bentuk simpanan dan menyalurkannya kepada masyarakat dalam bentuk kredit dan atau bentuk-bentuk lainnya dalam rangka meningkatkan taraf hidup rakyat banyak. Menurut kasmir dalam bukunya Manajemen Perbankan (2010:11), bank diartikan sebagai lembaga keuangan yang kegiatan utamanya adalah menghimpun dana dari masyarakat dan menyalurkan kembali dana tersebut kepada masyarakat serta memberikan jasa bank lainnya. 
Kemudian Muchdarsyah sinungan (2000) mengatakan bank adalah suatu lembaga keuangan yang berfungsi sebagai financial intermediary atau perantara keuangan dari dua pihak, yaitu pihak yang kelebihan dana dan pihak yang kekurangan dana. Muchdarsyah juga mengatakan bank adalah suatu lembaga keuangan yang usaha pokoknya memberikan kredit dan jasa-jasa lalu lintas pembayaran dan peredaran uang.

Dalam beberapa hal, bank konvensional dan bank syariah memiliki persamaan, terutama dalam sisi teknis penerimaan uang, mekanisme transfer, teknologi computer yang digunakan, syarat-syarat umum memperoleh pembiayaan seperti KTP, NPWP, proposal, laporan keuangan, dan sebagainya. Akan tetapi, terdapat banyak perbedaan mendasar diantara keduanya. Perbedaan itu menyangkut aspek legal, struktur organisasi, usaha yang dibiayai, dan lingkungan kerja (Muhammad Syafi'i Antonio:2001).
Bank Islam atau selanjutnya disebut dengan Bank Syariah, adalah bank yang beroperasi dengan tidak berorientasi pada bunga. Bank dengan prinsip syariah dijelaskan pada pasal 1 butir 13 UndangUndang No. 10 Tahun 1998 tentang perbankan, bahwa Prinsip syariah adalah aturan perjanjian berdasarkan hukum islam antara bank dan pihak lain untuk penyimpanan dana dan atau pemibiayaan kegiatan usaha, atau kegiatan lainnya yang dinyatakan sesuai dengan prinsip syariah, antara lain pembiayaan berdasarkan prinsip bagi hasil (Mudharabah), Pembiayaan berdasarkan prinsip penyertaan modal (Musyarakah), prinsip jual beli (Murabahah), atau pembiayaan barang modal berdasarkan prinsip sewa murni tanpa pilihan (Ijarah) atau dengan adanya pilihan pemindahan kepemilikan atas barang yang disewa dari pihak bank oleh pihak lain (Ijarah Wa Itiqna).

\section{Data Envelopment Analysis (DEA)}

DEA adalah sebuah metode optimasi program matematika yang 
dipergunakan untuk mengukur efisiensi teknis suatu unit kegiatan ekonomi (UKE) dan membandingkan secara relatif terhadap UKE lain (Rica, 2010). Dalam konsep DEA yang dipopulerkan oleh Charnes, Cooper dan Rhodes (CCR) pada tahun 1978 terdapat dua pendekatan atau asumsi dalam menghitung efisiensi dengan menggunakan DEA. Diamana Efisiensi teknis dan efisiensi profitabilitas dinyatakan dengan presentase. Apabila presentase semakin mendekati 100\%, maka unit kegiatan ekonomi semakin efisien.

Penghitungan efisiensi menggunakan DEA dengan asumsi CCR atau biasa disebut Constant Return to Scale (CRS) dan BCC/Variable Return to Scale (VRS) dilakukan karena keduanya saling melengkapi. Para peneliti ini pertama kali menemukan model DEA CCR (Charnes-Cooper-Rhodes) pada tahun 1978. Menurut Purwanto (2012) model ini mengasumsikan adanya Constant Return to Scale (CRS). CRS adalah perubahan proposional yang sama pada tingkat input akan menghasilkan perubahan proposional yang sama pada tingkat output (misalnya: penambahan 1 persen input akan menghasilkan penambahan 1 persen output). Pendekatan VRS berasumsi bahwa bank dapat saja menghasilkan kurang atau lebih dari satu output (Elvira, 2012).

Alasan penggunaan DEA, yaitu (1) pemberian bobot penilaian untuk setiap variabel penentu kinerja dilakukan secara objektif, (2) DEA merupakan analisis titik ekstrim yang berbeda dengan tendensi pusat, sehingga setiap observasi atau unit kegiatan ekonomi dianalisis secara individual, (3) DEA membentuk referensi hipotesis (virtual production function) berdasar pada data observasi yang ada (Samsubar, 2000).

Dalam metode DEA, efiseinsi relatif suatu UKE didefinisikan sebagai rasio dari total output tertimbang dibagi dengan total input tertimbang sehingga inti dari metode DEA adalah menentukan 
bobot atau timbangan untuk setiap input dan output UKE dimana bobot tersebut memiliki sifat tidak negatif serta bersifat universal yang artinya setiap UKE dalam sampel harus dapat mempergunakan seperangkat bobot yang sama untuk mengevaluasi rasionya dan rasio tersebut tidak lebih dari 1 (Rica, 2010).

DEA memiliki asumsi bahwa setiap UKE akan memilih bobot yang memaksimalkan rasio efisiensinya. Karena setiap UKE menggunakan kombinasi input yang berbeda untuk menghasilkan kombinasi output yang mencerminkan keragaman tersebut, dan bobot tersebut bukan merupakan nilai ekonomis dari input atau output melainkan penentu untuk memaksimalkan efisiensi dari suatu UKE.

Menurut Muharam dan Pusvitasari (2007) terdapat 3 pendekatan yang lazim digunakan baik dalam metode parametrik Stochastic Frontier Analysis (SFA) dan Distribution Free Analysis (DFA) maupun non parametrik Data Envelopment Analysis (DEA) untuk mendefinisikan hubungan input dan output dalam kegiatan finansial suatu lembaga keuangan yaitu:

1. Pendekatan Aset (The asset Approach) Pendekatan aset mencerminkan fungsi primer sebuah lembaga keuangan sebagai pencipta kredit pinjaman (loans). Dekat sekali dengan pendekatan intermediasi, dimana output benar-benar didefinisikan ke dalam bentuk aset.

2. Pendekatan Produksi (The Production Approach)

Pendekatan ini menganggap lembaga keuangan sebagai produsen dari akun deposito (deposit account) dan kredit pinjaman (credit account) lalu mendefinisikan output sebagai jumlah dari akun - akun tersebut atau dari transaksi-transaksi yang terkait. Inputinput dalam kasus ini dihitung sebagai jumlah dari tenaga kerja, pengeluaran modal pada aset-aset tetap dan material lainya.

3. Pendekatan Intermediasi (The Intermediation Approach) 
Pendekatan ini menggambarkan kegiatan perbankan sebagai lembaga intermediasi yang mentrasformasi dana dari deposan (surplus spending unit) kepada peminjam (deficit spending unit) atau yang merubah dan mentransfer aset-aset finansial dari unit-unit surplus menjual unit-unit defisit. Pendekatan ini mendefinisikan input sebagai financial capital seperti simpanan, biaya tenaga kerja, dan modal. Serta output sebagai volume pembiayaan atau investment outstanding dan pendapatan dari kegiatan-kegiatan lain yang menghasilkan pendapatan.

\section{Efisiensi Bank Umum Syariah dengan} DEA

Penelitian ini mengukur tingkat efisiensi teknik menggunakan metode DEA dengan pendekatan intermediasi dan produksi, karena isu yang paling menonjol menimbulkan perdebatan adalah mengenai posisi dari deposits dari kedua pendekatan tersebut. Dimana dalam pendekatan intermediasi memandang bank sebagai perantara antara penabung dan pengguna (investor). Dan dalam pendekatan produksi memandang bank sebagai proses produksi dari pelayanan penabung dan pengguna.

Berkaitan dengan dua bentuk pendekatan fungsi bank, sebagian peneliti berpendapat bahwa deposits harus dipandang sebagai output, sementara sebagian yang lainnya melihat deposits sebagai input. Berg et al. (1992) mengemukakan bahwa deposits harus diperlakukan sebagai output karena pengumpulan deposits merupakan proses kegiatan yang mengkonsumsi sumber daya (resource consuming activities). Sedangkan Berger et al. (1993) sebaliknya berargumentasi bahwa deposits seharusnya diperlakukan sebagai input sehubungan dengan adanya biaya (bunga) yang dikeluarkan bank untuk memperolehnya. Pada umumnya, biaya bunga bahkan merupakan komponen terbesar dari total biaya sebuah lembaga perbankan. 
Dalam konsep DEA yang

dipopulerkan oleh Charnes, Cooper dan Rhodes (CCR) pada tahun 1978 terdapat dua pendekatan atau asumsi dalam menghitung efisiensi dengan menggunakan DEA. Diamana Efisiensi teknis dan efisiensi profitabilitas dinyatakan dengan presentase. Apabila presentase semakin mendekati $100 \%$, maka unit kegiatan ekonomi semakin efisien.

Berdasarkan latar belakang yang telah diuraikan sebelumnya mengenai salah satu cara mengetahui kinerja perbankan syariah di Indonesia dapat dilihat dari tingkat efisiensinya, sehingga tujuan dalam penelitian ini adalah untuk mengukur nilai Efisiensi Bank Umum Syariah (studi pada 10 bank umum syariah devisa dan non devisa) selama periode 2013-2017 menggunakan metode Data Envelopment Analysis (DEA) dengan Intermediation approach dan Production approach.

\section{METODE PENELITIAN}

\section{Variabel Penelitian}

Dalam penelitian ini efisiensi dari tiap variabel diukur menggunakan metode DEA dengan pendekatan intermediasi dan produksi. Variabel penelitian ini untuk pendekatan intermediasi terdiri dari variable input yaitu simpanan, modal dan biaya tenaga kerja. Dan variabel outputnya adalah pembiayaan/kredit dan total pendapatan.

Variabel dalam pendekatan produksi terdiri dari variabel input yaitu modal, asset tetap dan biaya tenga kerja. Serta variabel outputnya adalah pembiayaan/kredit dan simpanan.

Dalam penelitian ini efisiensi dari tiap variabel diukur menggunakan metode DEA dengan pendekatan intermediasi dan produksi.

\section{Penentuan Sampel}

Data dalam penelitian ini diperoleh dengan mengumpulkan data historis yang bersumber dari Bank Indonesia. Sumber 
data yang diperoleh dalam penelitian ini adalah data sekunder yaitu laporan keuangan Bank Umum Syariah (busn devisa dan busn non devisa) yang dipublikasikan oleh Bank Indonesia selama periode 2013-2017. Populasi yang digunakan dalam penelitian ini adalah seluruh Bank Umum Syariah (busn devisa dan busn non devisa) yang terdaftar di Bank Indonesia pada tahun 2013-2018. Sedangkan untuk pengambilan sampel data penelitian ini dilakukan secara purposive sampling artinya metode pemilihan sampel dipilih berdasarkan pertimbangan (judgement sampling) yang berarti pemilihan sampel secara tidak acak yang informasinya diperoleh dengan pertimbangan tertentu. Kriteria sampel yang digunakan adalah sebagai berikut:

a. Bank Umum Syariah yang beroperasi di Indonesia selama periode pengamatan 2013-2017;

b. Bank Umum Syariah yang termasuk dalam Bank Umum Swasta Nasional Devisa dan Non Devisa c. Secara konsisten tidak mengalami perubahan bentuk badan usaha pada periode pengamatan 2013-2018, menyajikan laporan keuangan pada periode pengamatan 2013-2017 dan telah dipublikasikan di Bank Indonesia;

d. Menyajikan laporan keuangan yang lengkap pada periode pengamatan 2013-2017 dan telah dipublikasikan di Bank Indonesia.

\section{Metode Analisis}

Metode analisis yang digunakan untuk menguji hipotesis dalam penelitian ini adalah statistik deskriptif untuk menggambarkan tingkat efisiensi teknik pada Bank Umum Syariah (busn devisa dan busn non devisa).

Didalam penelitian ini, peneliti menggunakan metode DEA dengan Langkah- langkah analisis sebagai berikut:

1. Pengukuran Efisiensi Kinerja Bank dengan menggunakan DEA berdasarkan Output Oriented (Maximum Output). Analisis nilai 
efisiensi dengan pendekatan

intermediasi yang berasumsikan CRS

dan VRS untuk Bank Umum Syariah

(busn devisa dan busn non devisa) di

Indonesia periode 2013-2018.

2. Pengukuran Efisiensi Kinerja Bank

dengan menggunakan DEA

berdasarkan Output Oriented

(Maximum Output). Analisis nilai

efisiensi dengan pendekatan produksi

yang berasumsikan CRS dan VRS

untuk Bank Umum Syariah (busn devisa dan busn non devisa) di

Indonesia periode 2013-2018.

\section{HASIL PENELITIAN DAN}

PEMBAHASAN

\section{Deskripsi Objek Penelitian}

Berdasarkan teknik pengambilan sampel dengan menggunakan metode purposive sampling, didapat jumlah sampel sebagai berikut:

Tabel 1. Seluruh Sampel Berdasarkan Kriteria

\begin{tabular}{llc}
\hline No & \multicolumn{1}{c}{ Kriteria } & Jumlah \\
\hline 1 & BUS (busn devisa dan non devisa) yang terpublikasi di Bank Indonesia tahun & 10 \\
& $2013-2018$ & 10 \\
2 & Jumlah sampel & 50 \\
& Total data tahun (10 X 5 tahun) & \\
\hline
\end{tabular}

\section{Deskripsi Variabel}

Tabel 2. Uji Deskriptif Data Efisiensi

\begin{tabular}{|l|r|r|r|r|r|}
\hline & $\mathrm{N}$ & \multicolumn{1}{|c|}{ Minimum } & Maximum & \multicolumn{1}{c|}{ Mean } & \multicolumn{1}{c|}{ Std. Deviation } \\
\hline Kel_Bank & 50 & 1 & 10 & 5.50 & 2.901 \\
Intermediasi_CRS & 50 & 66.53 & 100.00 & 93.7592 & 8.26503 \\
Intermediasi_VRS & 50 & 69.00 & 100.00 & 96.1792 & 6.42977 \\
Produksi_CRS & 50 & 6.90 & 100.00 & 75.5784 & 25.90734 \\
Produksi_VRS & 50 & 18.20 & 100.00 & 82.6580 & 22.95965 \\
Valid N (listwise) & 50 & & & & \\
\hline
\end{tabular}


Dari hasil analisis statistik deskriptif tersebut baik untuk pendekatan intermediasi dan produksi, dapat disimpulkan bahwa pola sebaran data cukup konsisten untuk dapat diterima sebagai karakter sampel yang sebenarnya (tidak bias) sehingga informasi dapat digunakan untuk mengambil kesimpulan.

\section{Pembahasan Hasil Penelitian}

Analisis tingkat efisiensi perbankan Syariah periode 2013-2018 menggunakan metode DEA. Hasil analisa perhitungan efisiensi perbankan akan dibahas berdasarkan pendekatan intermediasi dan pendekatan produksi

\section{Bank Umum Syariah}

Tabel 3. Hasil Perhitungan Efisiensi BUS dengan Pendekatan Intermediasi

\begin{tabular}{|c|c|c|c|c|c|c|c|c|c|c|}
\hline \multirow{2}{*}{ Nama Bank } & \multicolumn{2}{|c|}{2013 (persen) } & \multicolumn{2}{|c|}{2014 (persen) } & \multicolumn{2}{|c|}{2015 (persen) } & \multicolumn{2}{|c|}{2016 (persen) } & \multicolumn{2}{|c|}{2017 (persen) } \\
\hline & CRS & VRS & CRS & VRS & CRS & VRS & CRS & VRS & CRS & VRS \\
\hline BNI Syariah & 89.95 & 97.81 & 93.20 & 93.30 & 99.10 & 99.10 & 87.70 & 88.10 & 90.20 & 96.50 \\
\hline $\begin{array}{l}\text { Bank Mega } \\
\text { Syariah }\end{array}$ & 95.47 & 97.16 & 100.00 & 100.00 & 100.00 & 100.00 & 95.90 & 96.50 & 100.00 & 100.00 \\
\hline $\begin{array}{l}\text { Bank } \\
\text { Muamalat }\end{array}$ & 90.93 & 100.00 & 100.00 & 100.00 & 100.00 & 100.00 & 100.00 & 100.00 & 100.00 & 100.00 \\
\hline $\begin{array}{l}\text { Bank Syariah } \\
\text { Mandiri }\end{array}$ & 100.00 & 100.00 & 98.00 & 100.00 & 100.00 & 100.00 & 100.00 & 100.00 & 100.00 & 100.00 \\
\hline BCA Syariah & 73.45 & 82.40 & 66.96 & 69.00 & 91.40 & 92.70 & 93.40 & 93.90 & 96.90 & 98.40 \\
\hline BRI Syariah & 86.08 & 95.34 & 100.00 & 100.00 & 90.70 & 91.10 & 84.30 & 85.30 & 91.00 & 92.50 \\
\hline $\begin{array}{l}\text { Bank Jabar } \\
\text { Banten } \\
\text { Syariah }\end{array}$ & 77.59 & 78.00 & 86.31 & 86.50 & 100.00 & 100.00 & 100.00 & 100.00 & 100.00 & 100.00 \\
\hline $\begin{array}{l}\text { Bank Panin } \\
\text { Syariah }\end{array}$ & 91.88 & 97.20 & 96.15 & 96.45 & 100.00 & 100.00 & 100.00 & 100.00 & 97.10 & 97.50 \\
\hline $\begin{array}{l}\text { Bank Syariah } \\
\text { Bukopin }\end{array}$ & 100.00 & 100.00 & 91.90 & 98.70 & 98.80 & 99.20 & 93.50 & 94.70 & 90.40 & 91.60 \\
\hline $\begin{array}{l}\text { Bank Victoria } \\
\text { Syariah }\end{array}$ & 66.53 & 100.00 & 92.56 & 100.00 & 100.00 & 100.00 & 100.00 & 100.00 & 90.60 & 100.00 \\
\hline $\begin{array}{l}\text { Pencapaian } \\
\text { Rata-rata }\end{array}$ & 87 & 95 & 93 & 94 & 98 & 98 & 95 & 96 & 96 & 98 \\
\hline
\end{tabular}

Pencapaian rata-rata efisiensi

teknik BUS yang berasumsikan CRS mengalami fluktuasi dari tahun 2013-2017, dimana tahun 2013 sampai 2015 mengalami kenaikan yaitu 87 persen
(2013), 93 persen (2014) dan 98 persen (2015). Pada tahun 2016 mengalami penurunan menjadi 95 persen. Dan pada tahun 2018 mengalami kenaikan kembali menjadi 96 persen. Pencapaian rata-rata 
efisiensi teknik BUS yang berasumsikan

VRS dalam pendekatan intermediasi

mengalami fluktuasi selama tahun 2013-

2018, dimana pada tahun 2014 mengalami

penurunan menjadi 94 persen dari 95

persen (2013). Dan mengalami kenaikan

pada tahun 2015 menjadi 98 persen,

kemudian pada tahun 2016 mengalami

penuruan menjadi 96 persen. Dan naik kembali pada tahun 2017 menjadi 98 persen.

Dari tabel 3 dapat menunjukkan bahwa pencapaian rata-rata efisiensi teknik BUS dengan pendekatan intermediasi pada tahun 2013-2017, yang berasumsikan VRS lebih tinggi atau efisien dibandingkan dengan berasumsikan CRS.

Tabel 4. Hasil Perhitungan Efisiensi BUS dengan Pendekatan Produksi

\begin{tabular}{|c|c|c|c|c|c|c|c|c|c|c|}
\hline \multirow{2}{*}{ Nama Bank } & \multicolumn{2}{|c|}{2013 (persen) } & \multicolumn{2}{|c|}{2014 (persen) } & \multicolumn{2}{|c|}{2015 (persen) } & \multicolumn{2}{|c|}{2016 (persen) } & \multicolumn{2}{|c|}{2017 (persen) } \\
\hline & CRS & VRS & CRS & VRS & CRS & VRS & CRS & VRS & CRS & VRS \\
\hline BNI Syariah & 100.00 & 100.00 & 100.00 & 100.00 & 83.40 & 85.30 & 85.60 & 87.10 & 74.80 & 77.20 \\
\hline $\begin{array}{l}\text { Bank Mega } \\
\text { Syariah }\end{array}$ & 98.00 & 99.70 & 79.56 & 80.90 & 50.10 & 57.40 & 39.30 & 46.00 & 48.10 & 60.10 \\
\hline Bank Muamalat & 100.00 & 100.00 & 100.00 & 100.00 & 100.00 & 100.00 & 100.00 & 100.00 & 100.00 & 100.00 \\
\hline $\begin{array}{l}\text { Bank Syariah } \\
\text { Mandiri }\end{array}$ & 100.00 & 100.00 & 100.00 & 100.00 & 100.00 & 100.00 & 100.00 & 100.00 & 100.00 & 100.00 \\
\hline BCA Syariah & 100.00 & 100.00 & 73.70 & 91.10 & 28.70 & 39.80 & 30.60 & 37.70 & 44.00 & 56.30 \\
\hline BRI Syariah & 87.89 & 88.30 & 100.00 & 100.00 & 77.50 & 79.30 & 77.00 & 78.60 & 94.80 & 98.90 \\
\hline $\begin{array}{l}\text { Bank Jabar } \\
\text { Banten Syariah }\end{array}$ & 61.63 & 63.40 & 81.03 & 83.20 & 48.60 & 54.40 & 56.90 & 64.70 & 79.60 & 96.20 \\
\hline $\begin{array}{l}\text { Bank Panin } \\
\text { Syariah }\end{array}$ & 100.00 & 100.00 & 100.00 & 100.00 & 50.50 & 55.60 & 6.90 & 18.20 & 9.00 & 18.50 \\
\hline $\begin{array}{l}\text { Bank Syariah } \\
\text { Bukopin }\end{array}$ & 100.00 & 100.00 & 97.18 & 100.00 & 69.20 & 79.10 & 58.30 & 67.30 & 54.70 & 68.60 \\
\hline $\begin{array}{l}\text { Bank Victoria } \\
\text { Syariah }\end{array}$ & 72.10 & 100.00 & 88.63 & 100.00 & 61.80 & 100.00 & 59.10 & 100.00 & 50.70 & 100.00 \\
\hline $\begin{array}{l}\text { Pencapaian } \\
\text { Rata-rata }\end{array}$ & 92 & 95 & 92 & 96 & 67 & 75 & 61 & 70 & 66 & 78 \\
\hline
\end{tabular}

Pencapaian rata-rata efisiensi

teknik BUS yang berasumsikan CRS

dalam pendekatan produksi mengalami

fluktuasi dari tahun 2013-2017, dimana

tahun 2013 dan 2014 tidak mengalami perubahan yaitu 92 persen. Pada tahun 2015 dan 2016 mengalami penurunan yaitu 67 persen dan 61 persen. Dan pada tahun 2017 mengalami kenaikan yaitu 66 persen. Pencapaian rata-rata efisiensi 
teknik BUS yang berasumsikan VRS

dalam pendekatan produksi mengalami

fluktuasi selama tahun 2013-2017, dimana

pada tahun 2014 mengalami kenaikan

menjadi 96 persen dari 95 persen (2013).

Dan mengalami penurunan pada tahun

2015 dan 2016 menjadi 75 persen dan 70 persen. Kemudian pada tahun 2017 mengalami kenaiakan menjadi 78 persen.

Dari tabel 4 dapat menunjukkan bahwa pencapaian rata-rata efisiensi teknik BUS dengan pendekatan produksi pada tahun 2013-2017, yang berasumsikan VRS lebih tinggi atau efisien dibandingkan dengan berasumsikan CRS.

Tabel 5. Rata-rata Nilai Efisiensi 2013-

2017

\begin{tabular}{lcccc}
\hline \multirow{2}{*}{ Nama Bank } & \multicolumn{2}{c}{ Mean Intermediasi } & \multicolumn{2}{c}{ Mean Produksi } \\
& CRS & VRS & CRS & VRS \\
\hline BNI Syariah & 92.03 & 94.96 & 88.76 & 89.92 \\
Bank Mega Syariah & 98.27 & 98.73 & 63.01 & 68.82 \\
Bank Muamalat & 98.19 & 100.00 & 100.00 & 100.00 \\
Bank Syariah Mandiri & 99.60 & 100.00 & 100.00 & 100.00 \\
BCA Syariah & 84.42 & 87.28 & 55.40 & 64.98 \\
BRI Syariah & 90.42 & 92.85 & 87.44 & 89.02 \\
Bank Jabar Banten Syariah & 92.78 & 92.90 & 65.55 & 72.38 \\
Bank Panin Syariah & 97.03 & 98.23 & 53.28 & 58.46 \\
Bank Syariah Bukopin & 94.92 & 96.84 & 75.88 & 83.00 \\
Bank Victoria Syariah & 89.94 & 100.00 & 66.47 & 100.00 \\
\hline Pencapaian Rata-rata & 93.76 & 96.18 & 75.58 & 82.66 \\
\hline
\end{tabular}

Dari tabel 5 menunjukkan bahwa bank yang konsisten efisien 100 persen dari tahun 2013-2017 adalah Bank Muamalat pada pendekatan intermediasi yang berasumsikan VRS, dan pada pendekatan produksi yang berasumsikan baik CRS maupun VRS. Bank Mandiri Syariah konsisten efisien 100 persen dari tahun 2013-2017 pada pendekatan intermediasi yang berasumsikan VRS serta pada pendekatan produksi yang berasumsikan CRS dan VRS. Dan Bank Victoria Syariah konsisten efisien 100 persen dari tahun 2013-2017 pada pendekatan intermediasi dan pendekatan produksi yang berasumsikan VRS. 
Dimana Bank Muamalat dan Bank Syariah Mandiri merupakan Bank Umum Syariah

Devisa. Sedangkan Bank Victoria Syariah merupakan Bank Umum Syariah Non Devisa.

\section{KESIMPULAN, KETERBATASAN}

DAN SARAN

\section{Kesimpulan}

Dari 10 bank yang menjadi sampel penelitian (4 bank umum syariah devisa dan 6 bank umum syariah non devisa) dengan pendekatan intermediasi dan produksi, rata-rata pencapaian efisiensi baik bank umum syariah devisa dan non devisa selama periode 2013-2017. Dari hasil rata-rata pencapaian nilai efisiensi bank yang berasumsikan VRS mendapatkan nilai yg lebih tinggi atau lebih efisien dibandingkan yang berasumsikan CRS. Hal ini dikarenakan dalam asumsi CRS bahwa rasio penambahan input sama dengan penambahan output adalah sama (constant return to scale), artinya penambahan " $\mathrm{X}$ " input akan menambah jumlah "X" output.
Sedangkan dalam asumsi VRS bahwa rasio penambahan input dan output tidak sama (variable return to scale) ini berarti penambahan input sebesar ' $\mathrm{X}$ " tidak selalu menghasilkan output sebesar " $X$ " kali, bisa lebih besar dan bisa lebih kecil. Dalam dunia perbankan, nyatanya setiap penambahan input tidak selalu menghasilkan penambahan output yang sama nilainya, bisa jadi bertambahnya lebih besar atau lebih sedikit nilainya.

Hasil penelitian ini menunjukkan bahwa terdapat tiga Bank Umum Syariah yang konsisten efisien 100 persen dari tahun 2013-2014 yaitu Bank Muamalat dan Bank Syariah Mandiri 2017 pada pendekatan intermediasi yang berasumsikan VRS dan pada pendekatan produksi yang berasumsikan CRS dan VRS.

Serta Bank Bank Victoria Syariah pada pendekatan intermediasi dan pendekatan produksi yang berasumsikan VRS. Dimana Bank Muamalat dan Bank Syariah Mandiri merupakan Bank Umum Syariah Devisa. 
Sedangkan Bank Victoria Syariah

merupakan Bank Umum Syariah Non

Devisa.

\section{Keterbatasan Penelitian}

1. Berkaitan dengan metode DEA yang hanya dapat mengukur efisiensi relatif (karena hanya dibandingkan dengan bank-bank dalam sampel) sehingga sangat memungkinkan tidak mencerminkan efisiensi sebenarnya dari bank-bank yang diteliti.

2. Keterbatasan jumlah sampel yang digunakan (hanya 4 bank umum syariah devisa dan 6 bank umum Syariah non devisa) karena adanya keterbatasan sumber data yang mampu diperoleh oleh penulis dan software yang digunakan tidak bisa lebih dari 20 sampel bank.

3. Jumlah sampel hanya terbatas pada kelompok bank bank umum syariah saja, belum melihat kelompok unit usaha syariah dan BPR syariah.

4. Periode waktu penelitian yang masih terbatas.

\section{Saran Penelitian}

Berdasarkan analisa dan kesimpulan yang telah diuraikan di atas terdapat beberapa masukan bagi pihakpihak terkait dan bagi penelitian yang akan datang, antara lain:

1. Dengan nilai efisiensi yang cukup baik dan ada beberapa bank syariah yang konsisten mencapai efisiensi 100 persen dari tahun 2013-2017, maka baik nasabah maupun calon nasabah yang akan menitipkan dananya pada bank dapat menjadikan bank syariah sebagai referensi dalam memilih bank yang tepat sesuai pilihannya. Serta jika ingin terhindar dari riba, maka bank syariah merupakan pilihan yang tepat.

2. Bagi bank umum syariah yang belum mampu mencapai tingkat efisiensi sempurna 100 persen, sebaiknya perlu membenahi kembali tingkat penggunaan input dan output yang dicapainya. Artinya bahwa input yang tersedia sebaiknya dimanfaatkan secara optimal (seminimal mungkin) agar 
mampu menghasilkan output dari target yang ditetapkan (semaksimal mungkin). Ada baiknya juga bagi bank yang inefisien untuk mencontoh tingkat penggunaan input dan output dari acuan bank yang efisien agar dapat meningkatkan efisiensinya sehingga dapat mencapai tingkat efisiensi sempurna 100 persen.

3. Bagi penelitian yang akan datang disarankan untuk menggunakan jumlah sampel yang lebih banyak seperti unit usaha syariah, BPR syariah dan dapat membandingkan antar nilai efisiensinya. Serta menggunakan software yang lebih baik lagi yang dapat mengoperasikan dengan jumlah sampel yang lebih banyak. Dengan harapan untuk memperoleh hasil penelitian yang lebih optimal dan mampu menggambarkan efisiensi perbankan syariah nasional secara keseluruhan.

\section{DAFTAR PUSTAKA}

Abidin, Zaenal. 2007. Analisis Eksistensi. Jakarta: PT Raja Grafindo Persada.

Abidin, Zaenal, dan Endri. 2009. Kinerja Efisiensi Teknis Bank Pembangunan Daerah: Pendekatan Data Envelopment Analysis (DEA). Jurnal Akuntansi dan Keuangan, Vol. 11, No. 1.

Ahmad Syakir Kurnia, 2004. Mengukur Efisiensi Intermediasi Sebelas Bank Terbesar Indonesia Dengan Pendekatan Data Envelopment Analysis (DEA). Jurnal Bisnis Strategi Vol. 13/Desember/2004, hal. 126-140.

Amanda, Rica. 2010. Analisis Efisiensi Teknis Bidang Pendidikan dalam Implementasi Model Kota Layak Anak. Universitas Diponegoro Semarang. 
Antonio, Muhammad Syafi'i, 2001. Bank Syariah dari Teori ke Praktik.

Gema Insani Press, Jakarta.

Bank Indonesia. 2014. Laporan Keuangan

Bank Umum Konvensional dan

Bank Umum Syariah Tahunan

Publikasi

2014.

(http://www.bi.go.id).

Berger, Peter L., Berger, Brigitte., Kellner,

Hansfried. 1992. The Homeless

Mind, Modernization and

Consciousness, atau Pikiran

Kembara, terj. Widyamartaya, A.

Yogyakarta: Penerbit Kanisius.

Berger C. Blauth R. Boger D. et al. 1993.

Kano methods for understanding

customer-defined quality.

Hinshitsu: Journal of the

Japanese Society for Quality

Control.

Charnes, A., Cooper and Rhodes, E. 1978.

Measuring the Efficiency of

Decision Making Units.

European Journal of Operational

Research, Vol.2.
Elvira, Finta. 2012. Efisinesi Teknis dan Efisiensi Profitabilitas Perbankan

Sebelum dan Setelah Krisis

Ekonomi 2008 dengan menggunakan Metode Non

Parametrik Data Envelopment Analysis (DEA). Universitas

Dipanegoro, Semarang.

Golany, B. and J.E. Storbeck. 1999. A Data Envelopment Analysis of the Operational Efficiency of Bank Branches. Interfaces 29(3).

H, Muharram dan Pusvitasari R. 2007. Analisis Perbandingan Efisiensi Bank Syariah di Indonesia dengan Metode Data Envelopment Analysis (Periode 2005). Jurnal Ekonomi dan Bisnis Islam, Vol II, No. 3, Yogyakarta.

Hadad, Muliaman D. dkk. 2003. Analisis Efisiensi Industri Perbankan Indonesia: Penggunaan Metode Non Parametrik Data Envelopment Analysis (DEA). 
Working Paper Series Bank

Indonesia, 3.

Handoko, T. Hani. 1984. Dasar - dasar

Manajemen Produksi dan

Operasi. Yogyakarta: BPFE -

Yogyakarta.

Republik Indonesia. Undang-Undang

tentang Peraturan Bank Indonesia

Nomor 9/7 Tahun 2007.

• Undang-Undang tentang
Peraturan Bank Indonesia Nomor

14/26 Tahun 2012.

Undang-Undang tentang

Peraturan Bank Indonesia Nomor

2/19 Tahun 2000.

Sinungan, Muchdarsyah. Drs. 2000.

Manajemen Dana Bank. Jakarta:

PT Budi Aksara.

Soteriou, A., and Zenios, Stavros A.

(1999). Efficiency Cost

Operations, Quality and

Profitability in the Provition of

Service. Management

Science/Vol. 45, No. 9,

September 1999 pp. 1221-1238.
Statistik Perbankan Indonesia.

Statistik/Laporan Keuangan

publikasi/2015. www.go.id.

Subekti, I. 2004. Investigasi empiris CostEfficiency Perbankan Indonesia berdasarkan Metode Data Envelopment Analyisis (DEA). Lintasan Ekonomi, 95-115.

Desmy Riani

dari Fakultas Ekonomi dan Bisnis

Universitas Ibn Khaldun Bogor 